\title{
Efficacy of Disinfection of Rigid Endoscope by Ethyl Alcohol 70\%
}

\author{
Marco Cesar J. Santos ${ }^{1,2,3(0)}$ Henrique F. Pauna ${ }^{2,3}$ \\ ${ }^{1}$ Department of Ophthalmology and Otorhinolaryngology, Faculdade \\ de Medicina, Universidade de São Paulo, São Paulo, SP, Brazil \\ 2 Hospital IPO, Curitiba, PR, Brazil \\ ${ }^{3}$ Department of Otorhinolaryngology, Hospital Universitário Cajuru, \\ Curitiba, PR, Brazil \\ ${ }^{4}$ Escola de Enfermagem, Universidade de São Paulo, São Paulo, SP, \\ Brazil
}

Int Arch Otorhinolaryngol 2022;26(3):e460-e466.

\begin{abstract}
Keywords

- detergents

- disinfection

- endoscopy

- ethanol

Introduction Currently, there is no safe, affordable, and ecologically-sustainable guideline that helps prevent contamination through endoscopy. We evaluated the safety of intermediate-level disinfection with $70 \%$ ethyl alcohol $(\mathrm{w} / \mathrm{v})$ based on biological-load recovery from rigid endoscopes after nasal endoscopy.

Objective To demonstrate the efficacy of $70 \%$ ethanol in disinfecting rigid endoscopes (REs) to reduce microbial growth in microbiological cultures.

Methods After a nasal endoscopy examination, the endoscope was swabbed with gauze; this served as the positive-control sample. The standard operating procedure for intermediate-level disinfection with $70 \%$ ethyl alcohol (w/v) following prior cleaning was applied. The endoscope was again swabbed; this served as the experimental sample. The collected material from the endoscope was extracted from gauze pieces, filtered through a $0.22-\mu \mathrm{m}$ cellulose membrane, and cultivated in different means of culture.

Results The results revealed a significant difference between the positive-control and experimental groups regarding the presence of Streptococcus coagulase $(-)(p<0.001)$, Bacillus spp. $(p<0.001)$, and Staphylococcus aureus $(p=0.001)$. These microorganisms were detected in the control group, but not in the experimental group.

Conclusions Microorganisms were not recovered from the samples of the experimental group, demonstrating the efficacy and the germicidal action of $70 \%$ ethyl alcohol $(w / v)$ as a means of achieving intermediate-level disinfection.
\end{abstract}

\author{
Address for correspondence Henrique F. Pauna, MD, PhD, Avenida \\ República Argentina 2.069, Curitiba, PR, 80620-110, Brazil \\ (e-mail: h_pauna@hotmail.com).
}

\section{Introduction}

Nasal endoscopy is a simple otorhinolaryngological procedure commonly used to inspect the nasal cavity and paranasal sinuses and provide complete visibility of these structures. Ear, nose, and throat (ENT) specialists regularly employ rigid or flexible instruments to perform these techniques. It is not uncommon for the same endoscope to be used on several patients in the same day. However, there is no safe, clear, affordable, and ecologically-sustainable received

March 23, 2021

accepted

November 2, 2021

published online

January 31, 2022
DOI https://doi.org/ 10.1055/s-0042-1742330. ISSN 1809-9777.

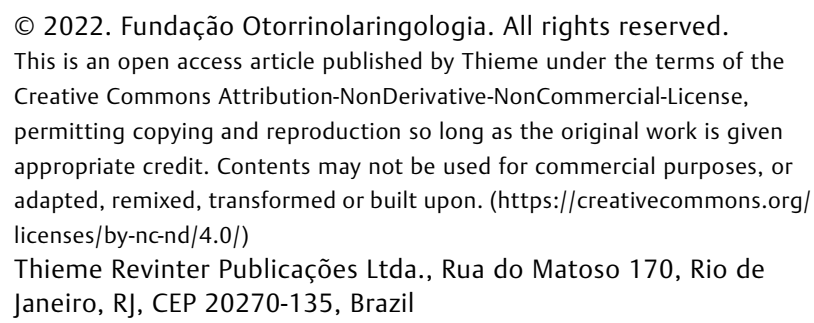

(c) 2022. Fundação Otorrinolaringologia. All rights reserved. This is an open access article published by Thieme under the terms of the Creative Commons Attribution-NonDerivative-NonCommercial-License, permitting copying and reproduction so long as the original work is given appropriate credit. Contents may not be used for commercial purposes, or adapted, remixed, transformed or built upon. (https://creativecommons.org/ licenses/by-nc-nd/4.0/) Thieme Revinter Publicações Ltda., Rua do Matoso 170, Rio de Janeiro, RJ, CEP 20270-135, Brazil 
guideline that provides easily accessible products for reprocessing, and that can be applied in any office, clinic, outpatient facility, or hospital. This lack of standardization may lead to inadequate cleaning of the equipment, resulting in the possibility of iatrogenic infection.

Previous studies ${ }^{1-3}$ have described the low risk of contamination through endoscopy. In 1993, the American Society for Gastrointestinal Endoscopy reported the likelihood of infection of 1 in every $1,800,000$ endoscopic procedures performed (0.000056\%). However, this study assessed endoscopes used in gastroenterology and pneumology, which have a complex shape with a lumen, one of which is a biopsy channel. ${ }^{1}$ However, the endoscopes used in otorhinolaryngology have a smooth surface and no biopsy channel. Earle $\mathrm{H}$. Spaulding ${ }^{1}$ classified different health products according to the potential risk of transmission of microorganisms. This resulted in a rational new approach to the disinfection and sterilization of medical products and equipments. ${ }^{2}$

Unlike sterilization, disinfection is not sporicidal. A few disinfectants will kill spores with prolonged exposure times (from 3 to 12 hours) and are named sterilants. At similar concentrations but shorter exposure times, these disinfectants will kill most microorganisms (except bacterial spores), and they are called high-level disinfectants. Low-level disinfectants can kill most bacteria, some fungi, and some viruses. Lastly, intermediate-level disinfectants might kill mycobacteria, vegetative bacteria, most viruses, and most fungi, but not necessarily bacterial spores. Thus, the development of standard operating protocols (SOPs) for endoscope reprocessing remains a fundamental need in the everyday medical practice. Many disinfectants can be used at the intermediate level, but $70 \%$ ethyl alcohol $(\mathrm{w} / \mathrm{v})$ ethanol - is generally sufficient. Alcohol exhibits rapid antimicrobial action against vegetative bacteria (including some species of mycobacteria), viruses, and fungi, but is not sporicidal; it can only inhibit sporulation and germination by preventing the production of metabolites essential for rapid cellular division, which only occurs when organic material is present on the surface of the instruments. ${ }^{3,4}$ Therefore, the goal of the present study was to demonstrate the efficacy of $70 \%$ ethanol in disinfecting rigid endoscopes (REs) to reduce microbial growth in microbiological cultures.

\section{Materials and Methods}

The present study was approved by the institutional Ethics in Research Committee.

From the outpatient clinic of our department, we randomly selected patients who presented nasal symptoms (such as nasal obstruction, rhinorrhea, or loss of smell) and underwent a nasal endoscopic examination with an RE. We excluded pediatric patients and those in a postoperative stage within a period of 3 months after surgery. A total of 38 patients were included after the informed consent form was signed.

Before every new endoscopic examination, the RE was cleaned and disinfected in a hard rectangular plastic box that had been previously cleaned and disinfected with $70 \%$ ethyl alcohol (w/v). It had an approximate volume of $2 \mathrm{~L}$, and was sufficiently tall for the liquid to completely cover the instrument. A volume of $3 \mathrm{~mL}$ of enzymatic detergent (Riozyme IV, Rioquimica, São José do Rio Preto, SP, Brazil) was added to $1 \mathrm{~L}$ of water and mixed as per the manufacturer's instructions. The endoscope was immersed in this solution immediately after the examination, and then removed from the solution after the duration suggested by the manufacturer and rinsed with running potable water while being scrubbed with a soft bristle brush to remove debris. The brush was then visually checked to ensure that the equipment was clean. This step was repeated as many times as necessary, as the absence of debris is the determining factor for optimal intermediatelevel disinfection. The liquid in which the endoscope was immersed was left in the sink. The plastic box was rinsed thoroughly until no enzymatic detergent remained. The box was thoroughly dried by hand using a paper towel. After drying, a piece of gauze with $70 \%$ ethyl alcohol (w/v) was rubbed over the entire surface of the hard plastic box for 30 seconds. A fresh detergent solution and a clean box were used for each new reprocessing, as recommended in a 2012 resolution by the Brazilian Health Regulatory Agency (Agência Nacional de Vigilância Sanitária, Anvisa, in Portuguese)..$^{5}$

After nasal endoscopy was performed, the following sequence of procedures was applied:

a) The material on the surface of the RE was swabbed and collected with dry gauze - prior to any disinfection. This material represented the basal load of the samples for further analysis, and was considered our control group ( $N=38$ samples). The samples from the control group were harvested with a piece of gauze with saline solution (0.9\%). The gauze was swabbed for 30 seconds after the performance of the nasal endoscopy. The gauze was then immersed in a sterile flask with $250 \mathrm{~mL}$ of saline solution and assigned a number.

b) Continuous scrubbing with $70 \%$ ethyl alcohol (w/v) for 30 seconds, with intervals of 10 seconds and repeating the process 2 times more. This was considered our standardized operational procedure (SOP).

c) The remaining material on the surface of the RE was again swabbed and collected with a dry gauze. This material was considered our experimental group ( $N=38$ samples). After intermediate-level disinfection, a sample from the experimental group was collected with a piece of gauze with saline solution $(0.9 \%)$ and immersed in a different sterile flask with $250 \mathrm{~mL}$ of saline solution and assigned a number.

The 76 samples (38 samples from each group) were subjected to indirect microbial extraction by filtration through a membrane. These samples (pieces of gauze) were placed in their own screw-top glass flask containing $250 \mathrm{~mL}$ of $0.9 \%$ saline solution. Each glass flask was identified by sample number and whether it contained a sample from the control or experimental groups.

To remove the microbial load from the gauze, the flask was sonicated for 5 seconds 3 times (USC-2800, Enge 
Solutions, São Paulo, SP, Brazil), and then subjected to 10 minutes of orbital agitation (Kline, model 255 B, Fanem, São Paulo, SP, Brazil) at $160 \mathrm{rpm}$. This technique was used based on previous studies on microbial load extraction from health care materials. ${ }^{6,7}$

The extract was then subjected to membrane filtration using a system established by the United States Pharmacopeia (Rockville, MD, United States). ${ }^{8}$ Autoclave filtration (47mm Sterifil Holder, Millipore, Billerica, MA, United States) was performed using a funnel with a lid, a supported filter base, and a silicone lid that was connected to a Kitassato flask (-Fig. 1), which, in turn, was connected to a vacuum pump. The volume of the glass flask was divided into 3 portions containing $50 \mathrm{~mL}$ and 1 containing $100 \mathrm{~mL}$, each separated by a filtration membrane. The membranes were cultured in petri dishes, each containing a specific type of agar: blood agar for the non-selective growth of aerobic bacteria; chocolate agar for the growth of anaerobic bacteria; and Sabouraud agar for the growth of filamentous fungi. The final dish was divided in half with a disposable scalpel. In one half, the membrane was cultured in Löwenstein-Jensen medium to grow microbacteria, while the other half contained fluid thioglycollate medium that enables the growth of anaerobic microorganisms. The blood agar, Sabouraud, LöwensteinJensen, and thioglycollate dishes were incubated at $37^{\circ} \pm 2^{\circ}$ $\mathrm{C}$, while the chocolate agar dishes were placed in anaerobiosis jars and incubated at the same temperature.

The samples were placed in hermetically-sealed thermal boxes and transported to the microbiology laboratory, where the microorganisms were quantified and identified by genus and species.

The results were described in terms of frequencies and percentages. Since samples from both study groups were evaluated, the groups were compared regarding the presence

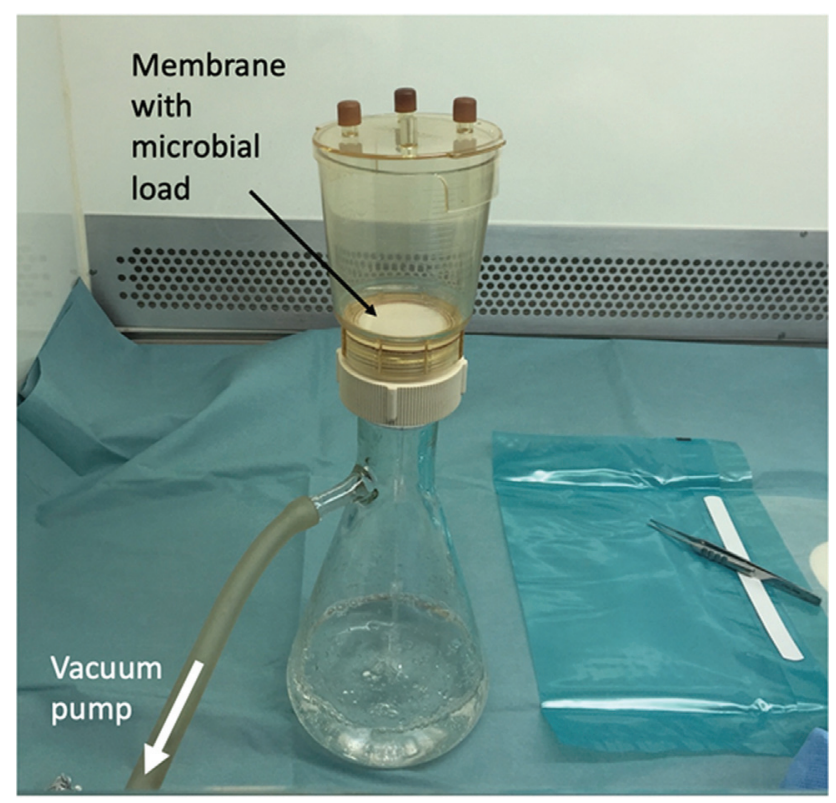

Fig. 1 The extract obtained from the rigid endoscope was then subjected to membrane filtration using a funnel with a lid, a supported filter base, and a silicone lid that was connected to a Kitassato flask. of microorganisms using a binomial test. Values of $p<0.05$ were considered statistically significant. The data was analyzed using the Statistical Package for the Social Sciences (IBM SPSS Statistics for Windows, IBM Corp., Armonk, NY, United States) software, version 20.0.

\section{Results}

The results of each group are presented individually and include a description of the microorganisms detected in the samples and a comparison of the groups regarding the presence of microorganisms (-Table $\mathbf{1}$ ).

Microorganisms were detected in 34 out of the 38 samples (89.5\%). In total, 67 microorganisms were detected, $\sim 1.8$ microorganisms per sample.

The experimental group showed no growth of microorganisms. The statistical analysis revealed a significant difference between both groups regarding the presence of Streptococcus coagulase $(-) \quad(p<0.001)$, Bacillus spp. $(p<0.001)$, and Staphylococcus aureus $(p=0.001)$. In the samples from the control group, these organisms were detected at rates of $63.2 \%, 28.9 \%$, and $28.9 \%$ in the control group samples respectively, but they were not detected in the samples from the experimental group (-Table 2 ). Overall, there was a significant difference between the groups regarding the presence of the microorganisms analyzed $(p<0.001)$. Notably, even using appropriate means for the growth and recovery of mycobacteria, this difference was not observed in the control group at any time point, even after 60 days of incubation.

\section{Discussion}

Our results demonstrate that this disinfection protocol can be applied safely to the daily clinical work. The intermediatelevel disinfection of REs used in otolaryngological examinations was shown to be effective. Thus, this protocol exhibits the fungicidal and bactericidal action expected of $70 \%$ ethyl alcohol (w/v) as an intermediate-level disinfectant.

Infections related to endoscopic examinations are very rare. In 2006, a systematic review ${ }^{6}$ found 69 outbreaks of exogenic infections related to endoscopy; these outbreaks involved 740 patients, and were reported in medical articles and shared with the Food and Drug Administration (FDA) between 1966 and 2005. Not all infections related to endoscopic exams are reported, but these data strongly suggest that the risk of infection is very low, considering that at least 11 million endoscopic procedures are performed in the United States each year. In most cases, bronchoscopy or gastrointestinal endoscopy were performed, for which the reported incidence of infection in the United States is estimated as 1 in 1.8 million procedures. ${ }^{9}$ Interestingly, in 2005 , Oakley et al. ${ }^{10}$ found that there were no studies reporting infection related to nasal endoscopy, Which is in line with the paper by Fokkens et al., ${ }^{11}$ who found no studies connecting nasal endoscopy to bacterial or viral rhinitis or rhinosinusitis in their etiology guidelines. 
Table 1 Results for isolated microorganisms detected in control-group samples $(N=38)$

\begin{tabular}{|c|c|c|c|c|c|c|c|c|}
\hline \multirow[t]{2}{*}{ Sample } & \multicolumn{2}{|l|}{ Isolate 1} & \multicolumn{2}{|l|}{ Isolate 2} & \multicolumn{2}{|l|}{ Isolate 3} & \multicolumn{2}{|l|}{ Isolate 4} \\
\hline & Microorganism & CFU & Microorganism & CFU & Microorganism & CFU & Microorganism & CFU \\
\hline 1 & $\begin{array}{l}\text { Streptococcus } \\
\text { coagulase (-) }\end{array}$ & 154 & $\begin{array}{l}\text { Streptococcus } \\
\text { spp. }\end{array}$ & 154 & & & & \\
\hline 2 & S. coagulase (-) & $>300$ & Bacillus spp. & 60 & & & & \\
\hline 3 & S. coagulase (-) & 19 & Bacillus spp. & 16 & & & & \\
\hline 4 & $\begin{array}{l}\text { Staphylococcus } \\
\text { aureus }\end{array}$ & $>300$ & $\begin{array}{l}\text { Gram-positive } \\
\text { Bacillus }\end{array}$ & 1 & & & & \\
\hline 5 & S. coagulase (-) & $>300$ & & & & & & \\
\hline 6 & S. coagulase (-) & 140 & Bacillus spp. & $>300$ & Candida spp. & 44 & & \\
\hline 7 & S. coagulase $(-)$ & 4 & Bacillus spp. & 42 & & & & \\
\hline 8 & S. coagulase (-) & 256 & Neisseria spp. & $>300$ & & & & \\
\hline 9 & S. coagulase (-) & 17 & Bacillus spp. & 80 & S. aureus & 12 & & \\
\hline 10 & S. coagulase (-) & 100 & Neisseria spp. & 130 & Micrococcus spp. & 4 & & \\
\hline 11 & S. aureus & 20 & & & & & & \\
\hline 12 & (-) 48 hours & & & & & & & \\
\hline 13 & (-) 48 hours & & & & & & & \\
\hline 14 & (-) 48 hours & & & & & & & \\
\hline 15 & (-) 48 hours & & & & & & & \\
\hline 16 & S. coagulase (-) & Outgrowth & & & & & & \\
\hline 17 & S. aureus & Outgrowth & P. rettgeri & Outgrowth & & & & \\
\hline 18 & S. coagulase $(-)$ & Outgrowth & S. aureus & Outgrowth & & & & \\
\hline 19 & S. coagulase (-) & Outgrowth & & & & & & \\
\hline 20 & S. aureus & $1+$ outgrowth & & & & & & \\
\hline 21 & $\begin{array}{l}\text { Klebsiella } \\
\text { Pneumoniae }\end{array}$ & $4+$ outgrowth & & & & & & \\
\hline 22 & S. aureus & 100 & $\begin{array}{l}\text { Citrobacter } \\
\text { diversus }\end{array}$ & Outgrowth & $\begin{array}{l}\text { Klebsiella } \\
\text { Oxytoca }\end{array}$ & Outgrowth & P. rettgeri & Outgrowth \\
\hline 23 & S. coagulase (-) & Outgrowth & & & & & & \\
\hline 24 & Providencia Rettgeri & Outgrowth & & & & & & \\
\hline 25 & S. coagulase (-) & $13+$ outgrowth & & & & & & \\
\hline 26 & S. coagulase (-) & Outgrowth & & & & & & \\
\hline 27 & Micrococcus spp. & 1 & S. coagulase (-) & 50 & Bacillus spp. & 3 & & \\
\hline 28 & Proteus mirabilis & $>300$ & & & & & & \\
\hline 29 & S. coagulase (-) & 240 & S. aureus & 1 & Bacillus spp. & 4 & & \\
\hline 30 & S. coagulase (-) & 3 & & & & & & \\
\hline 31 & S. coagulase (-) & $>300$ & Bacillus spp. & 50 & Micrococcus spp. & 3 & & \\
\hline 32 & S. coagulase (-) & 200 & S. aureus & 2 & Bacillus spp. & 30 & $\begin{array}{l}\text { Gram-positive } \\
\text { coccobacillus }\end{array}$ & 11 \\
\hline 33 & S. coagulase (-) & 50 & Micrococcus spp. & 3 & Bacillus spp. & 280 & & \\
\hline 34 & S. aureus & $>300$ & & & & & & \\
\hline 35 & S. aureus & $>300$ & $\begin{array}{l}\text { Non-group A and } \\
\text { non-group B } \\
\text { Streptococci }\end{array}$ & 200 & & & & \\
\hline 36 & S. coagulase (-) & 60 & Micrococcus spp. & 35 & $\begin{array}{l}\text { Viridans group } \\
\text { Streptococcus }\end{array}$ & 50 & & \\
\hline 37 & S. coagulase (-) & 150 & Bacillus spp. & 60 & & & & \\
\hline 38 & S. coagulase $(-)$ & 4 & $\begin{array}{l}\text { Gram-positive } \\
\text { coccobacillus }\end{array}$ & 2 & & & & \\
\hline
\end{tabular}

Abbreviation: CFU, colony-forming units. 
Table 2 Characteristics of the samples isolated from the study groups

\begin{tabular}{|c|c|c|c|c|c|c|}
\hline \multirow[t]{2}{*}{ Technique } & \multirow[t]{2}{*}{ Microorganism } & \multicolumn{2}{|c|}{ Control group } & \multicolumn{2}{|c|}{$\begin{array}{l}\text { Experimen- } \\
\text { tal group }\end{array}$} & \multirow[t]{2}{*}{$p$-value } \\
\hline & & $n$ & $\%$ & $\mathbf{n}$ & $\%$ & \\
\hline \multirow[t]{17}{*}{ Isolated } & Streptococcus coagulase (-) & 24 & 63.2 & 0 & 0 & $<0.001$ \\
\hline & Bacillus spp. & 11 & 28.9 & 0 & 0 & $<0.001$ \\
\hline & Staphylococcus aureus & 11 & 28.9 & 0 & 0 & 0.001 \\
\hline & Micrococcus spp. & 5 & 13.2 & 0 & 0 & 0.062 \\
\hline & Providencia rettgeri & 3 & 7.9 & 0 & 0 & 0.250 \\
\hline & Neisseria spp. & 2 & 5.3 & 0 & 0 & 0.500 \\
\hline & Gram-positive coccobacillus & 2 & 5.2 & 0 & 0 & 0.500 \\
\hline & Gram-positive Bacillus & 1 & 2.6 & 0 & 0 & 1 \\
\hline & Citrobacter diversus & 1 & 2.6 & 0 & 0 & 1 \\
\hline & Candida spp. & 1 & 2.6 & 0 & 0 & 1 \\
\hline & Klebsiella oxytoca & 1 & 2.6 & 0 & 0 & 1 \\
\hline & Klebsiella pneumoniae & 1 & 2.6 & 0 & 0 & 1 \\
\hline & Proteus mirabilis & 1 & 2.6 & 0 & 0 & 1 \\
\hline & Viridans group Streptococcus & 1 & 2.6 & 0 & 0 & 1 \\
\hline & Non-group A and non-group B Streptococci & 1 & 2.6 & 0 & 0 & 1 \\
\hline & Streptococcus spp. & 1 & 2.6 & 0 & 0 & 1 \\
\hline & General (any microorganism) & 34 & 89.5 & 0 & 0 & $<0.001$ \\
\hline \multirow[t]{9}{*}{ FTM } & S. coagulase (-) & 24 & 63.2 & 0 & 0 & $<0.001$ \\
\hline & S. aureus & 9 & 23.7 & 0 & 0 & 0.004 \\
\hline & Neisseria spp. & 3 & 7.9 & 0 & 0 & 0.250 \\
\hline & C. diversus & 1 & 2.6 & 0 & 0 & 1 \\
\hline & K. pneumoniae & 1 & 2.6 & 0 & 0 & 1 \\
\hline & P. mirabilis & 1 & 2.6 & 0 & 0 & 1 \\
\hline & P. rettgeri & 1 & 2.6 & 0 & 0 & 1 \\
\hline & Streptococcus bovis & 1 & 2.6 & 0 & 0 & 1 \\
\hline & General (any microorganism) & 36 & 94.7 & 0 & 0 & $<0.001$ \\
\hline \multirow[t]{2}{*}{ Anaerobic } & Bacteroides spp. & 5 & 13.2 & 0 & 0 & 0.062 \\
\hline & General (any microorganism) & 5 & 13.2 & 0 & 0 & 0.062 \\
\hline \multirow[t]{4}{*}{ Sabouraud1 } & Candida albicans & 1 & 2.6 & 0 & 0 & 1 \\
\hline & Penicillium spp. & 3 & 7.9 & 2 & 5.3 & 1 \\
\hline & PC & 2 & 5.3 & 0 & 0 & 0.500 \\
\hline & General (any microorganism) & 6 & 15.8 & 2 & 5.3 & 0.125 \\
\hline
\end{tabular}

Abbreviation: FTM, fluid thioglycollate medium; PC, positive control.

Elackattu et al. ${ }^{12}$ found no uniform recommendations among American agencies regarding how flexible endoscopes should be disinfected between successive uses. They compared different methods to prevent contamination, specifically sterile and disposable coverings and germicidal liquids. While disposable coverings were not suitable for disinfection, even for flexible endoscopes, germicidal liquid showed adequate results. However, this does not prevent contamination by bacterial spores. Alcohols act as germicides because they exhibit bactericidal and bacteriostatic activity against vegetative forms of bacteria. It also acts against tuberculosis, fungi, and viruses. This fact supports the idea of using alcohol as an endoscope disinfectant in cases of microscopic rupture of the lining. ${ }^{12}$ In 1968, Spaulding $^{2}$ also observed decreased resistance to the germicidal potential of $70 \%$ ethyl alcohol from the most resistant organism to the least resistant one.

Previous studies ${ }^{13,14}$ have shown that microbial load is low on health care materials after cleaning, with a microbial reduction that rangea from $10^{2}$ to $10^{5}$ colonies formed per 
material. As the organisms die on a logarithmic scale, and at different times, a lower density of microbes at the beginning of the study results in a greater level of safety for decontamination. ${ }^{15,16}$ These studies showed greater safety in practice, as they started the disinfection process from a smaller inoculum load, which is obtained through the cleaning procedure.

Spaulding ${ }^{2}$ suggested that an optimal disinfectant must have rapid bactericidal action at a concentration that does not damage the material to be disinfected. Therefore, alcohols can be used because they rapidly destroy most types of vegetative bacteria. In contrast, they do not act against bacterial spores, which are only detected in the presence of debris or organic material, and are eliminated through an efficient cleaning process for endoscopes. Bacterial spores are not commonly found on the surface of REs because of the high turnover of this equipment.

High-level disinfection is potentially toxic. One of the most widely-used agents, glutaraldehyde, causes contact dermatitis, eye, nasal cavity and throat irritation, and occupational asthma. Therefore, reprocessing with glutaraldehyde is advised to be discontinued. Additionally, orthophthalaldehyde (OPA), often considered an alternative to glutaraldehyde, has been associated with irritation and allergic reactions in healthcare professionals, as well as anaphylactic reactions in patients. ${ }^{17}$ Furthermore, the oxidation of peracetic acid can cause serious burns, irreversible blindness, and nasal, throat, and lung irritation if inhaled. To avoid these toxic effects, these agents should be handled and discarded in strict conformity with prescribed protocols and guidelines, which may be difficult, particularly in large outpatient facilities. ${ }^{7}$

Cavaliere and Iemma ${ }^{18}$ evaluated the various methods of reprocessing thermosensitive endoscopes. They concluded that ideal reprocessing should account for: a) process standardization, avoiding errors, and negligence; b) rapid return of the endoscopes; c) traceability to guarantee the quality of reprocessing; d) reduction of contamination risk for the professionals involved in the process; and e) reduction of the risk of damage to the endoscopes. Therefore, the ideal disinfection system should be practical and based on human and economic resources, available space, volume of activity, and number of endoscopes. ${ }^{18}$

The endoscopes subjected to this intermediate-level protocol showed a significant reduction in microbial load to undetectable levels. McDonnell and Burke ${ }^{19}$ examined disinfection, originally proposed in 1957, to determine the possibility of reconsidering Spaulding's classification. ${ }^{19}$ The results of the present study coincide with those of McDonnell and Burke; ${ }^{19}$ thus, Spaulding's classification should be refined based on the advances in microbiological medicine over the past 60 years. Overall, 70\% ethyl alcohol (w/v) showed the expected germicidal action against microorganisms on the surface of endoscopes, as we observed no harmful bacteria growth after applying our study protocol, which suggests that there is no need to expose health care equipment, patients, and the environment to high levels of toxic disinfectants. This protocol has the further advantage of being immediately available for application and not requiring special handling of the instruments.

\section{Conclusion}

The present study demonstrated that an intermediatelevel disinfection applied to endoscopes used in the regular ENT practice was effective. Particularly, the use of $70 \%$ ethyl alcohol $(\mathrm{w} / \mathrm{v})$ according to our protocol demonstrated adequate bactericidal action, since no microorganisms were recovered from any samples in the experimental group.

\section{Financial Disclosure}

The authors declare that they have not received any funding pertaining to the present study.

\section{Conflict of Interests}

The authors have no conflict of interests to declare..

\section{References}

1 Spach DH, Silverstein FE, Stamm WE. Transmission of infection by gastrointestinal endoscopy and bronchoscopy. Ann Intern Med 1993;118(02):117-128. Doi: 10.7326/0003-4819-118-2199301150-00008

2 Spaulding EH. Chemical disinfection of medical and surgical materials. In: Lawrence C, Block SS, eds. Disinfection, sterilization, and preservation. Philadelphia: Lea \& Febiger; 1968:517-531

3 McDonnell G, Russell AD. Antiseptics and disinfectants: activity, action, and resistance. Clin Microbiol Rev 1999;12(01): 147-179

4 Rutala WA, Weber DJ. Guideline for disinfection and sterilization in healthcare facilities, 2008. Centers for Disease Control and Prevention (CDC) [Internet]. 2017 Feb 15 [cited 2017 Oct 20]. Available from: https://www.cdc.gov/infectioncontrol/pdf/guidelines/disinfection- guidelines.pdf

5 Brasil Ministério da Saúde Agência Nacional de Vigilância Sanitária. Resolução - RDC no 15, de 15 de março de 2012. Dispõe sobre requisitos de boas práticas para o processamento de produtos para saúde e dá outras providências [Internet]. [cited 2017 Nov 1]. Available from: http://bvsms.saude.gov.br/bvs/saudelegis/anvisa/2012/rdc0015_15_03_2012.h tml

6 Ribeiro SMCP. Reprocessamento de cateteres de angiografia cardiovascular após uso clínico e contaminados artificialmente: avaliação da eficácia da limpeza e da esterilização [thesis]. São Paulo: School of Nursing, University of São Paulo; 2006

7 Pinto FMG, de Souza RQ da Silva CB, Mimica LMJ, Graziano KU. Analysis of the microbial load in instruments used in orthopedic surgeries. Am J Infect Control 2010;38(03):229-233. Doi: 10.1016/j.ajic.2009.06.017

8 United States Pharmacopeia. 25th ed. Rockville: The United States Pharmacopeial Convention. USP 30-NF 25; 2007

9 Alvarado CJ, Reichelderfer M. Association for Professionals in Infection Control. APIC guideline for infection prevention and control in flexible endoscopy. Am J Infect Control 2000;28(02): 138-155. Doi: 10.1067/mic.2000.106054

10 Oakley RJ, Khemani S, Prior AJ, Terry RM. Decontamination of flexible nasendoscopes: is a call for guidelines too little too late? Clin Otolaryngol 2005;30(02):208-209. Doi: 10.1111/j.13652273.2004.00968.x

11 Fokkens WJ, Lund VJ, Mullol J, et al. EPOS 2012: European position paper on rhinosinusitis and nasal polyps 2012. A summary for otorhinolaryngologists. Rhinology 2012;50(01):1-12. Doi: 10.4193/Rhino50E2 
12 Elackattu A, Zoccoli M, Spiegel JH, Grundfast KM. A comparison of two methods for preventing cross-contamination when using flexible fiberoptic endoscopes in an otolaryngology clinic: disposable sterile sheaths versus immersion in germicidal liquid. Laryngoscope 2010;120(12):2410-2416. Doi: 10.1002/lary.21146

13 Rutala WA. APIC guideline for selection and use of disinfectants. 1994, 1995, and 1996 APIC Guidelines Committee. Association for Professionals in Infection Control and Epidemiology, Inc. Am J Infect Control 1996;24(04):313-342

14 Chan-Myers H, McAlister D, Antonoplos P. Natural bioburden levels detected on rigid lumened medical devices before and after cleaning. Am J Infect Control 1997;25(06):471-476. Doi: 10.1016/ S0196-6553(97)90070-5

15 Padoveze MC, Graziano KU. Aspectos conceituais e microbiológicos relacionados ao processamento de materiais utilizados na assistência à saúde. In: Graziano KU, Silva A. Psaltikidis EM, organizers. Enfermagem em centro de materiais e esterilização. São Paulo: Manole; 2010:22-61

16 Padoveze MC. Limpeza, desinfecção e esterilização: aspectos gerais. In: Padoveze MC, Graziano KU, coordinators. Limpeza, desinfecção e esterilização de artigos em serviços de saúde. São Paulo: APECIH; 2010:1-35

17 Liming B, Funnell I, Jones A, Demons S, Marshall K, Harsha W. An evaluation of varying protocols for high-level disinfection of flexible fiberoptic laryngoscopes. Laryngoscope 2014;124(11): 2498-2501. Doi: 10.1002/lary.24665

18 Cavaliere M, Iemma M. Guidelines for reprocessing nonlumened heat-sensitive ear/nose/throat endoscopes. Laryngoscope 2012; 122(08):1708-1718. Doi: 10.1002/lary.23389

19 McDonnell G, Burke P. Disinfection: is it time to reconsider Spaulding? J Hosp Infect 2011;78(03):163-170. Doi: 10.1016/j. jhin.2011.05.002 